\title{
Effect of Silicon on Incidence and Severity of Purple Blotch Disease (Alternaria porri (Ellis) Cif.) in Onion (Allium cepa L.)
}

\author{
Mohammad Haroon ${ }^{1,2}$, Amruta S. Bhat ${ }^{1}$, N.B. Prakash ${ }^{3}$, \\ K.T. Rangaswamy ${ }^{3}$ and H. B. Lingaiah ${ }^{1}$
}

${ }^{1}$ College of Horticulture, UHS Campus, GKVK, Bengaluru-560065, Karnataka, India

${ }^{2}$ Department of Plant Protection, Kandahar University, Afghanistan

${ }^{3}$ College of Agriculture, UAS, GKVK, Bengaluru-560065, India

*Corresponding author

\section{A B S T R A C T}

\section{Keywords}

Silicon, Onion, Purple blotch, Disease severity

Article Info

\section{Accepted:}

05 January 2020

Available Online:

10 February 2020

Effect of silicon on incidence and severity of purple blotch disease in onion was assessed by conducting field experiments at College of Horticulture Bengaluru. Silicon treatments significantly reduced the disease incidence and severity in two varieties (Bellary Red -Highly susceptible and Arka Kalyan - moderately resistant) of onion taken for the study. In both the varieties, least incidence and severity of disease was recorded in treatment receiving two sprays of silicic acid @ $4 \mathrm{ml} \mathrm{L}^{-1}$ which was superior to standard check (3 sprays of mancozeb @ $0.25 \%$ ) or other treatments followed by soil application of silicon@300 $\mathrm{kg} \mathrm{ha}^{-1}$. Silicic acid spray @ $4 \mathrm{ml} \mathrm{L}^{-1}$ reduced the disease incidence and severity by 34.88 and 28.93 per cent respectively in Bellary Red variety and it was reduced by 44.32 and 45.72 per cent respectively over untreated control in Arka Kalyan variety. Further, average bulb weight (Arka Kalyan- 58.33 g, Bellary Red $-63.40 \mathrm{~g}$ ) and total bulb yield (Arka Kalyan- $31.61 \mathrm{t} \mathrm{ha}^{-1}$, Bellary Red- $37.46 \mathrm{t} \mathrm{ha}^{-1}$ ) were also significantly higher with foliar application of silicic acid @ $4 \mathrm{ml} \mathrm{L}^{-1}$ in both the varieties over all other treatments. Hence, silicon application could be used as one of the ecofriendly strategies of purple blotch disease management in onion.

\section{Introduction}

Purple blotch disease caused by the fungus Alternaria porri (Ellis) Cif. is an important concern in onion production throughout the world and in India. The disease affects both bulb and seed crop and causes considerable yield loss. Management of this foliar disease mainly relies on frequent fungicidal sprays due to unavailability of resistant cultivars or other effective strategies. Continuous use of chemical fungicides in plant disease management has its own disadvantages. Fungicides may cause environmental 
pollution and health risk to humans. Further, resistant individuals within a fungal population may develop due to repeated application of the fungicides (Eckert, 1988). Holm et al., (2003) reported considerable variability in $A$. solani isolates to chlorothalonil and mancozeb due to repeated exposure. Chowdappa et al., (2012) studied the diversity of $A$. porri isolates collected from different onion production area of Karnataka state, South India and reported that the isolates were significantly different in their aggressiveness and sensitivity to fungicides.

Isolates collected were less sensitive to mancozeb which is used most commonly for managing purple blotch of onion. Hence, there is a need to search for safer alternatives to chemical pesticides for purple blotch disease management.

Silicon ( $\mathrm{Si}$ ) is the second most abundant element in the soil and is presently considered as a 'semi-essential' nutrient to plants (Romero et al., 2011). To date, many reports have documented the ability of Si to alleviate biotic and abiotic stress apart from its beneficial effects on growth and yield of crop. Silicon fertilization augmented grain and straw yield in rice with improved nutrient uptake (Malav et. al., 2015).

Soil application of silicon increased the leaf nutrient content and yield in sapota along with improved quality of fruits (Lalithya et. al., 2014). Silicon applied in the form of diatomaceous earth resulted in increased nutrient uptake, yield and quality of banana fruits (Kumbargire et. al., 2016).

Silicon increases the tolerance towards biotrophic, hemi-biotrophic and necrotrophic pathogens in both monocotyledons and dicotyledonous plant species (Fauteux et al., 2005, Cooke and Leishman, 2011). Silicon amendments and sprays have proved effective in controlling both soilborne and foliar fungal diseases in cucumber, rice, sugarcane, turf and several other plant species (Buck et al., 2008, Romero et al., 2011, Parkash et al., 2011, Kabalan et al., 2012). In rice, Si has been as effective as a fungicide in controlling rice blast (Magnaportha egrisea) and has even reduced the rate or number of necessary fungicide applications (Datnoff et al., 2001).

In addition, amending partially blast-resistant rice cultivars with $\mathrm{Si}$ increased their resistance to the same level as completely resistant cultivars (Seebold et al., 2000). In this context, silicon with its reported beneficial effects in reducing the disease in many other crop plants was thought of as an alternative and tested for the first time in onion for its effectiveness.

Hence, the present study was planned with an objective to know the effectiveness of both soil and foliar applied silicon on incidence and severity of purple blotch disease in onion.

\section{Materials and Methods}

Field experiments were conducted during Rabi season of 2013-14 at College of Horticulture, UHS campus, GKVK, Bengaluru. The location falls under eastern dry zone of Karnataka and is situated at $13^{\circ} 5^{\prime}$ North latitude, $77^{\circ}$ East longitude and at an altitude of $924 \mathrm{~m}$ above mean sea level.

Experiments were laid out in randomized complete block design with three replications. Each plot was of the size $2.1 \mathrm{~m} \times 1.5 \mathrm{~m}$. Onion seedlings were raised in the nursery bed and transplanted to main field with recommended dose of N P K (125:50:125 kg $\left.\mathrm{ha}^{-1}\right)$ and FYM (30 tha $\left.{ }^{-1}\right)$ as per package of practice of UHS Bagalkot (Anon. 2013). The crop was irrigated with drip irrigation system and harvested at proper maturity. 
Table.1 Effect of silicon on incidence of purple blotch disease in onion at different stages of crop growth

\begin{tabular}{|c|c|c|c|c|c|c|c|c|c|c|}
\hline \multirow[t]{3}{*}{ Treatments } & \multicolumn{10}{|c|}{ Disease incidence (\%) } \\
\hline & \multicolumn{5}{|c|}{ Arka Kalyan } & \multicolumn{5}{|c|}{ Bellary Red } \\
\hline & 35DAT & 45DAT & 55DAT & 65DAT & 95DAT & 35DAT & 45DAT & 55DAT & 65DAT & 95DAT \\
\hline $\mathbf{T}_{1}$-control & $\begin{array}{l}5.86 \\
(14.00)\end{array}$ & $\begin{array}{l}8.86 \\
(17.31)\end{array}$ & $\begin{array}{l}18.42 \\
(25.40)\end{array}$ & $\begin{array}{l}23.42 \\
(28.93)\end{array}$ & $\begin{array}{l}34.90 \\
(36.20)\end{array}$ & $\begin{array}{l}7.16 \\
(15.52)\end{array}$ & $\begin{array}{l}11.16 \\
(19.52)\end{array}$ & $\begin{array}{l}22.03 \\
(27.98)\end{array}$ & $\begin{array}{l}26.22 \\
(30.79)\end{array}$ & $\begin{array}{l}40.33 \\
(39.42)\end{array}$ \\
\hline $\begin{array}{l}\text { Th-Mancozeb } \\
@ \quad 2.5 \mathrm{~g} \mathrm{~L} \mathbf{L}^{-1} \\
\text { (3 sprays) }\end{array}$ & $\begin{array}{l}4.90 \\
(12.78)\end{array}$ & $\begin{array}{l}6.90 \\
(15.22)\end{array}$ & $\begin{array}{l}12.10 \\
(20.34)\end{array}$ & $\begin{array}{l}19.18 \\
(25.94)\end{array}$ & $\begin{array}{l}26.13 \\
(30.74)\end{array}$ & $\begin{array}{l}5.56 \\
(13.64)\end{array}$ & $\begin{array}{l}7.93 \\
(16.35)\end{array}$ & $\begin{array}{l}17.60 \\
(24.80)\end{array}$ & $\begin{array}{l}21.61 \\
(27.70)\end{array}$ & $\begin{array}{l}35.90 \\
(36.80)\end{array}$ \\
\hline $\begin{array}{l}T_{3} \text {-Silicon } \\
\text { soil } \\
\text { application } \\
\left(150 \mathrm{~kg} \mathrm{ha}^{-1}\right)\end{array}$ & $\begin{array}{l}4.90 \\
(12.78)\end{array}$ & $\begin{array}{l}6.73 \\
(15.03)\end{array}$ & $\begin{array}{l}12.46 \\
(20.66)\end{array}$ & $\begin{array}{l}15.26 \\
(22.97)\end{array}$ & $\begin{array}{l}24.73 \\
(29.81)\end{array}$ & $\begin{array}{l}5.56 \\
(13.64)\end{array}$ & $\begin{array}{l}8.26 \\
(16.70)\end{array}$ & $\begin{array}{l}18.20 \\
(25.24)\end{array}$ & $\begin{array}{l}19.73 \\
(26.36)\end{array}$ & $\begin{array}{l}34.26 \\
(35.82)\end{array}$ \\
\hline $\begin{array}{l}\mathbf{T}_{4^{-}} \quad \text { Silicon } \\
\text { soil } \\
\text { application } \\
\left(300 \mathrm{~kg} \mathrm{ha}^{-1}\right)\end{array}$ & $\begin{array}{l}4.86 \\
(12.74)\end{array}$ & $\begin{array}{l}6.50 \\
(14.76)\end{array}$ & $\begin{array}{l}10.20 \\
(18.62)\end{array}$ & $\begin{array}{l}13.20 \\
(21.27)\end{array}$ & $\begin{array}{l}23.63 \\
(29.08)\end{array}$ & $\begin{array}{l}5.36 \\
(13.39)\end{array}$ & $\begin{array}{l}7.70 \\
(16.10)\end{array}$ & $\begin{array}{l}16.06 \\
(23.62)\end{array}$ & $\begin{array}{l}16.50 \\
(23.95)\end{array}$ & $\begin{array}{l}29.33 \\
(32.79)\end{array}$ \\
\hline $\begin{array}{lrr}\mathbf{T}_{5^{-}} & \text {Silicic } \\
\text { acid } @ & \mathbf{2} \text { ml } \\
\mathrm{L}^{-1} & & (2 \\
\text { sprays }) & \end{array}$ & $\begin{array}{l}4.73 \\
(12.55)\end{array}$ & $\begin{array}{l}6.53 \\
(14.80)\end{array}$ & $\begin{array}{l}12.00 \\
(20.26)\end{array}$ & $\begin{array}{l}14.86 \\
(22.63)\end{array}$ & $\begin{array}{l}23.30 \\
(28.86)\end{array}$ & $\begin{array}{l}5.63 \\
(13.72)\end{array}$ & $\begin{array}{l}8.16 \\
(16.60)\end{array}$ & $\begin{array}{l}16.26 \\
(23.78)\end{array}$ & $\begin{array}{l}17.87 \\
(25.00)\end{array}$ & $\begin{array}{l}31.06 \\
(33.87)\end{array}$ \\
\hline $\begin{array}{ll}\text { T}_{6^{-}} & \text {Silicic } \\
\text { acid } & @ 2 \\
\text { ml } & \mathbf{L}^{-1}(\mathbf{3} \\
\text { sprays }) & \end{array}$ & $\begin{array}{l}4.66 \\
(12.47)\end{array}$ & $\begin{array}{l}6.53 \\
(14.80)\end{array}$ & $\begin{array}{l}10.26 \\
(18.68)\end{array}$ & $\begin{array}{l}14.73 \\
(22.55)\end{array}$ & $\begin{array}{l}22.53 \\
(28.33)\end{array}$ & $\begin{array}{l}5.30 \\
(13.30)\end{array}$ & $\begin{array}{l}7.83 \\
(16.25)\end{array}$ & $\begin{array}{l}14.86 \\
(22.67)\end{array}$ & $\begin{array}{l}17.70 \\
(24.88)\end{array}$ & $\begin{array}{l}27.36 \\
(31.54)\end{array}$ \\
\hline $\begin{array}{l}\mathrm{T}_{7-} \quad \text { Silicic } \\
\text { acid @ } 4 \mathrm{ml} \\
\mathrm{L}^{-1}(2 \text { sprays })\end{array}$ & $\begin{array}{l}4.26 \\
(11.91)\end{array}$ & $\begin{array}{l}6.10 \\
(14.29)\end{array}$ & $\begin{array}{l}9.93 \\
(18.37)\end{array}$ & $\begin{array}{l}13.30 \\
(21.32)\end{array}$ & $\begin{array}{l}19.43 \\
(26.13)\end{array}$ & $\begin{array}{l}5.30 \\
(13.30)\end{array}$ & $\begin{array}{l}7.50 \\
(15.89)\end{array}$ & $\begin{array}{l}12.83 \\
(20.99)\end{array}$ & $\begin{array}{l}14.43 \\
(22.32)\end{array}$ & $\begin{array}{l}24.83 \\
(29.88)\end{array}$ \\
\hline S.Em \pm & 0.21 & 0.17 & 0.42 & 0.83 & 0.16 & 0.22 & 0.19 & 0.33 & 0.42 & 0.41 \\
\hline CD at $5 \%$ & 0.65 & 0.54 & 1.31 & 2.56 & 0.52 & 0.69 & 0.60 & 1.02 & 1.31 & 1.27 \\
\hline
\end{tabular}

DAT- days after transplanting, *Figures in parenthesis indicate Arc sine transformed values 
Two varieties of onion viz., Bellary Red (highly susceptible) and Arka Kalyan (moderately resistant) were taken for the study. A total of seven treatments were imposed viz., $\mathrm{T}_{1}$ : Untreated control, $\mathrm{T}_{2}$ : Standard check - mancozeb (Indofil M-45 $75 \% \mathrm{WP}$ ) at 25, 40 and 55 days after planting, $\mathrm{T}_{3}$ : Silicon soil application@ $150 \mathrm{~kg} \mathrm{ha}^{-1}$ at the time of planting, $\mathrm{T}_{4}$ : Silicon soil application@300 kg ha ${ }^{-1}$ at the time of planting, $\mathrm{T}_{5}$ : Silicic acid spray @ $2 \mathrm{ml} \mathrm{L}^{-1}, 2$ sprays at 25 and 40 days after planting, $\mathrm{T}_{6}$ : Silicic acid spray@ $2 \mathrm{ml} \mathrm{L}^{-1}, 3$ sprays at 25 , 40 and 55 days after planting, $\mathrm{T}_{7}$ : Silicic acid spray@ $4 \mathrm{ml} \mathrm{L}^{-1}, 2$ sprays at 25 and 40 days after planting. In treatment 3 and 4, silicon was applied to the soil in the form of diatomaceous earth which was broadcasted to well-prepared plot and thoroughly mixed with the soil one day prior to transplanting.

For foliar application, soluble silicic acid was sprayed at the concentration of $2 \mathrm{ml} \mathrm{L}^{-1}$ or 4 $\mathrm{ml} \mathrm{L}^{-1}$ with a spray volume of $500 \mathrm{~L} \mathrm{ha}^{-1}$ using hand sprayer. Untreated check was sprayed with water and standard check (mancozeb) was sprayed at recommended concentration of $0.25 \%$. Observations on disease incidence and severity were recorded at 10 days interval starting from 35 days after transplanting (DAT) upto 65 days, and the final observation was recorded on $95^{\text {th }}$ day. Disease incidence was recorded for each treatment by counting the number of infected plants over total number of plants and is represented as percentage.

Disease severity was scored on ten plants in each treatment by following 0-5 scale as given by Sharma (1986). Yield observations like average bulb weight and bulb yield per plot were recorded for individual treatments. Available Si content of the experimental soil was analysed prior to start of the experiment according to Korndorfer et al., (2001). Silicon content in leaves and bulb was determined after harvesting the crop. Plant samples were dried in oven at $70^{\circ} \mathrm{C}$, powdered digested in microwave oven in acid $\left(\mathrm{HNO}_{3}\right.$ and $\left.\mathrm{HF}\right)$ medium as described by Ma et al., (2002). Silicon content in the sample was estimated and represented as percentage. Data were analysed statistically by the analysis of variance method at 5\% level of significance (Sundarraj et al., 1972).

\section{Results and Discussion}

Effect of silicon on incidence of purple blotch disease recorded at 35, 45, 55, 65 and 95 days after transplanting (DAT) indicated that at all the stages of observation, disease incidence was significantly higher in untreated control when compared to all other treatments in both the varieties (Table 1, Fig.1).

Disease incidence varied from 5.86 (35 DAT) to 34.90 (95 DAT) per cent in Arka Kalyan variety and in Bellary Red it varied from 7.16 (35 DAT) to 40.03 (95 DAT) per cent in untreated control. In Arka Kalyan variety, $\mathrm{T}_{7}$ (silicic acid spray @ $4 \mathrm{ml} \mathrm{L}^{-1}$ ) showed least incidence of disease and was superior to standard check or other treatments at all the stages of observation.

At early stages (up to 55 DAT) treatments viz., $\mathrm{T}_{3}$ (silicon soil application@ $150 \mathrm{~kg}$ ha 1) $\mathrm{T}_{4}$ ( silicon soil application @ $300 \mathrm{~kg} \mathrm{ha}^{-1}$ ) $\mathrm{T}_{5}$ (silicic acid spray @ $2 \mathrm{ml} \mathrm{L}^{-1}, 2$ sprays at 25 and 40 days after planting) $\mathrm{T}_{6}$ (silicic acid spray@2 $\mathrm{ml} \mathrm{L}^{-1}, 3$ sprays at 25, 40 and 55 days after planting) were on par with standard check and at later stages disease incidence was significantly less in these treatments than in the standard check. In Bellary Red variety, at 35 and 45 DAT, application of both soil and foliar silicon sources at different levels were on par with standard check and at 55, 65 and 95 DAT, $\mathrm{T}_{7}$ treatment (silicic acid spray @ $4 \mathrm{ml} \mathrm{L}^{-1}$ ) was best followed by $\mathrm{T}_{6}$ treatment ( 3 sprays of silicic acid@2 $\mathrm{ml} \mathrm{L}^{-1}$ ). 
Table.2 Effect of silicon on severity of purple blotch disease in onion at different stages of crop growth

\begin{tabular}{|c|c|c|c|c|c|c|c|c|c|c|}
\hline \multirow[t]{3}{*}{ Treatments } & \multicolumn{10}{|c|}{ Per cent disease index } \\
\hline & \multicolumn{5}{|c|}{ ArkaKalyan } & \multicolumn{5}{|c|}{ Bellary Red } \\
\hline & 35DAT & 45DAT & 55DAT & 65DAT & 95DAT & 35DAT & 45DAT & 55DAT & 65DAT & 95DAT \\
\hline $\mathrm{T}_{1}$-control & $\begin{array}{c}3.73 \\
(11.13)\end{array}$ & $\begin{array}{c}7.66 \\
(16.07)\end{array}$ & $\begin{array}{c}16.36 \\
(23.85)\end{array}$ & $\begin{array}{c}23.06 \\
(29.05)\end{array}$ & $\begin{array}{c}26.90 \\
(31.24)\end{array}$ & $\begin{array}{l}7.56 \\
(15.96)\end{array}$ & $\begin{array}{l}10.56 \\
(18.96)\end{array}$ & $\begin{array}{l}21.03 \\
(27.29)\end{array}$ & $\begin{array}{l}30.36 \\
(33.43)\end{array}$ & $\begin{array}{l}42.16 \\
(40.48)\end{array}$ \\
\hline $\begin{array}{l}\text { T2-Mancozeb } \\
\text { sprays })\end{array}$ & $\begin{array}{c}2.56 \\
(9.21)\end{array}$ & $\begin{array}{c}3.26 \\
(10.40)\end{array}$ & $\begin{array}{c}8.50 \\
(16.94)\end{array}$ & $\begin{array}{c}15.80 \\
(23.41)\end{array}$ & $\begin{array}{c}18.23 \\
(25.27)\end{array}$ & $\begin{array}{l}3.46 \\
(10.72)\end{array}$ & $\begin{array}{l}5.40 \\
(13.43)\end{array}$ & $\begin{array}{l}9.33 \\
(17.78)\end{array}$ & $\begin{array}{l}17.23 \\
(24.51)\end{array}$ & $\begin{array}{l}37.40 \\
(37.70)\end{array}$ \\
\hline $\begin{array}{l}\mathrm{T}_{3} \text {-Silicon soil application (150 } \\
\mathrm{kg} \mathrm{ha}^{-1} \text { ) }\end{array}$ & $\begin{array}{c}2.30 \\
(8.71)\end{array}$ & $\begin{array}{c}3.16 \\
(10.24)\end{array}$ & $\begin{array}{c}8.50 \\
(16.94)\end{array}$ & $\begin{array}{c}15.80 \\
(23.41)\end{array}$ & $\begin{array}{c}18.23 \\
(25.27)\end{array}$ & $\begin{array}{l}3.63 \\
(10.98)\end{array}$ & $\begin{array}{l}5.16 \\
(13.13)\end{array}$ & $\begin{array}{l}9.20 \\
(17.64)\end{array}$ & $\begin{array}{l}17.53 \\
(24.74)\end{array}$ & $\begin{array}{l}32.60 \\
(34.81)\end{array}$ \\
\hline $\begin{array}{l}\mathrm{T}_{4}-\text { Silicon soil application (300 } \\
\mathrm{kg} \mathrm{ha}^{-1} \text { ) }\end{array}$ & $\begin{array}{c}2.06 \\
(8.26)\end{array}$ & $\begin{array}{c}3.03 \\
(10.02)\end{array}$ & $\begin{array}{c}8.20 \\
(16.63)\end{array}$ & $\begin{array}{c}15.03 \\
(22.81)\end{array}$ & $\begin{array}{c}16.63 \\
(24.06)\end{array}$ & $\begin{array}{l}3.20 \\
(10.29)\end{array}$ & $\begin{array}{l}4.76 \\
(12.60)\end{array}$ & $\begin{array}{l}7.76 \\
(16.18)\end{array}$ & $\begin{array}{l}14.86 \\
(22.67)\end{array}$ & $\begin{array}{l}30.46 \\
(33.50)\end{array}$ \\
\hline $\begin{array}{l}\mathbf{T}_{5^{-}} \begin{array}{c}\text { Silicic acid } \\
\text { sprays })\end{array} \\
\text { @ }\end{array}$ & $\begin{array}{c}2.60 \\
(9.27)\end{array}$ & $\begin{array}{c}3.20 \\
(10.30)\end{array}$ & $\begin{array}{c}8.23 \\
(16.67)\end{array}$ & $\begin{array}{c}15.73 \\
(23.36)\end{array}$ & $\begin{array}{c}17.53 \\
(24.75)\end{array}$ & $\begin{array}{l}3.60 \\
(10.92)\end{array}$ & $\begin{array}{l}4.80 \\
(12.64)\end{array}$ & $\begin{array}{l}9.10 \\
(17.54)\end{array}$ & $\begin{array}{l}17.13 \\
(24.45)\end{array}$ & $\begin{array}{l}32.53 \\
(34.77)\end{array}$ \\
\hline 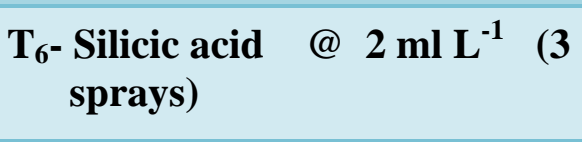 & $\begin{array}{c}2.53 \\
(9.14)\end{array}$ & $\begin{array}{c}3.43 \\
(10.67)\end{array}$ & $\begin{array}{c}8.30 \\
(16.74)\end{array}$ & $\begin{array}{c}14.90 \\
(22.70)\end{array}$ & $\begin{array}{c}17.33 \\
(24.60)\end{array}$ & $\begin{array}{l}3.56 \\
(10.87)\end{array}$ & $\begin{array}{l}4.76 \\
(12.60)\end{array}$ & $\begin{array}{l}9.13 \\
(17.58)\end{array}$ & $\begin{array}{l}17.06 \\
(24.39)\end{array}$ & $\begin{array}{l}32.73 \\
(34.89)\end{array}$ \\
\hline $\begin{array}{l}\mathrm{T}_{7}-\text { Silicic acid @ } 4 \mathrm{ml} \mathrm{L}^{-1} \text { (2 } \\
\text { sprays) }\end{array}$ & $\begin{array}{c}2.03 \\
(8.19)\end{array}$ & $\begin{array}{c}3.00 \\
(9.97)\end{array}$ & $\begin{array}{c}7.73 \\
(16.14)\end{array}$ & $\begin{array}{c}13.50 \\
(21.55)\end{array}$ & $\begin{array}{c}14.60 \\
(22.46)\end{array}$ & $\begin{array}{l}3.06 \\
(10.08)\end{array}$ & $\begin{array}{l}3.90 \\
(11.38)\end{array}$ & $\begin{array}{l}7.10 \\
(15.45)\end{array}$ & $\begin{array}{l}14.10 \\
(22.05)\end{array}$ & $\begin{array}{l}29.96 \\
(33.18)\end{array}$ \\
\hline S.Em \pm & 0.19 & 0.18 & 0.25 & 0.25 & 0.20 & 0.27 & 0.16 & 0.24 & 0.30 & 0.43 \\
\hline CD at $5 \%$ & 0.59 & 0.57 & 0.78 & 0.78 & 0.62 & 0.86 & 0.50 & 0.75 & 0.95 & 1.34 \\
\hline
\end{tabular}

DAT- days after transplanting, *Figures in parenthesis indicate Arc sine transformed values 
Similarly, severity of purple blotch disease at $35,45,55,65$ and 95 DAT varied significantly among the treatments (Table 2, Fig.2).

Severity of disease was significantly higher in untreated control when compared to all other treatments in both the varieties. In Arka Kalyan variety, disease severity varied from 3.73 (35 DAT) to 26.90 (95 DAT) per cent and in Bellary Red it varied from 7.56 (35 DAT) to 42.16 (95 DAT) per cent in untreated control. In both the varieties disease severity was least in $\mathrm{T}_{7}$ treatment (silicic acid spray @ $4 \mathrm{ml} \mathrm{L}^{-1}$ ) followed by $\mathrm{T}_{4}$ treatment (soil application of silicon@ $300 \mathrm{~kg} \mathrm{ha}^{-1}$ ) when compared to standard check or other treatments.

Further, disease severity was reduced by $28.93 \%$ in Bellary Red (highly susceptible) and $45.72 \%$ in Arka Kalyan (moderately resistant) variety over untreated check.
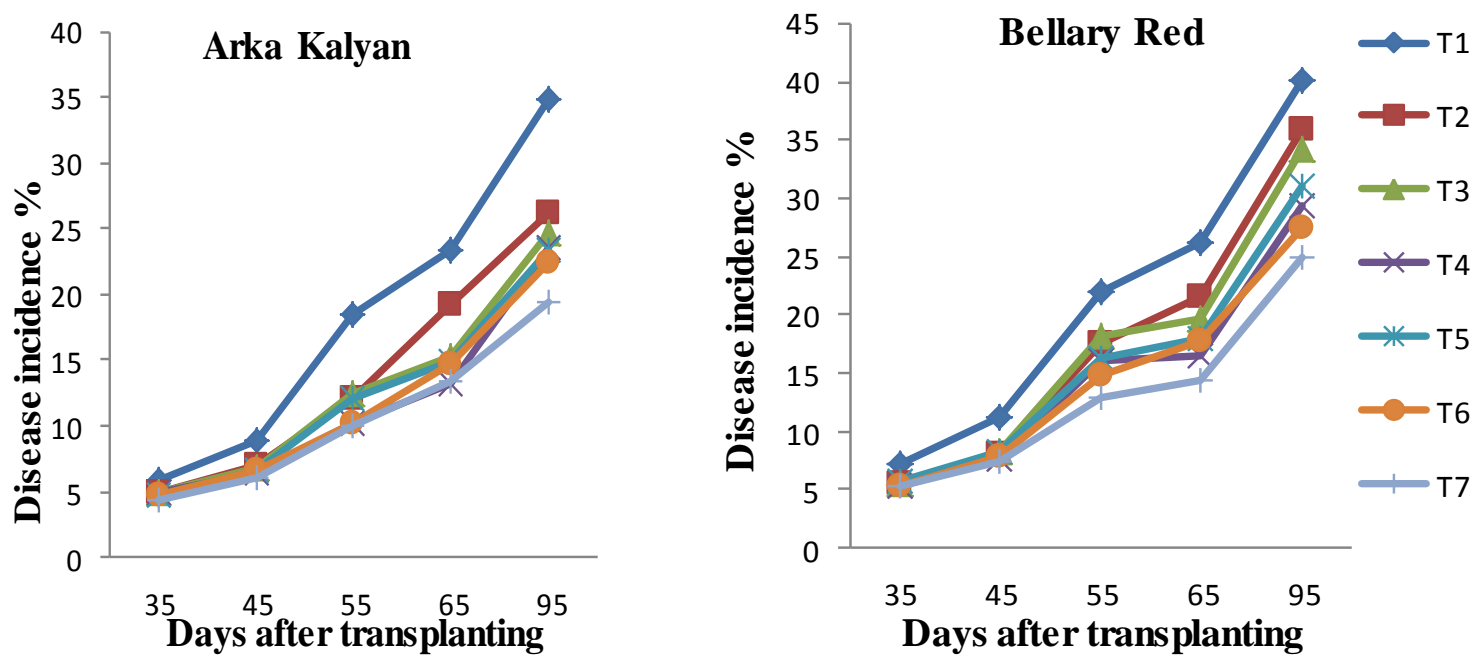

Fig.1 Effect of silicon on incidence of purple blotch disease in onion at different stages of crop growth

The present findings are in accordance with the results of Seebold et al., (2000) who reported that application of $\mathrm{Si}$ to the soil reduced the severity of leaf and neck blast of rice in partially resistant and susceptible cultivars in dose dependent manner. Buck et al., (2008) reported reduction in incidence of blast upon foliar application of silicon with greatest reduction at $4 \mathrm{~g} \mathrm{Si} \mathrm{L}^{-1}$.

Khaing et al., (2014) reported that the application of silicon has significantly minimized the sheath blight incidence and loss in yield in two varieties of rice which are moderately resistant (MR219) and moderately susceptible (MR253). Abdul Kareem et al., (2018) reported that the silicon treatment was on par with mancozeb application in reducing purple blotch disease in onion.

Reduction in disease severity with application of silicon has also been reported in many other host pathogen system such as, wheat powdery mildew system (Guével et al., 2007) asparagus-Phomopsis (Lu et al., 2008), soybean-rust (Lemes et al., 2011), cucurbits powdery mildew (Heckman et al., 2003), rose - powdery mildew (Shetty et al., 2012), banana-Mycosphaerella fijiensis (Kabalan et al., 2012). 
Table.3 Effect of silicon on average weight of bulb and bulb yield in onion

\begin{tabular}{|c|c|c|c|c|}
\hline \multirow[t]{2}{*}{ Treatments } & \multicolumn{2}{|c|}{ Average bulb weight (g) } & \multicolumn{2}{|c|}{ Bulb Yield (t/ha) } \\
\hline & Arka Kalyan & Bellary Red & Arka Kalyan & Bellary Red \\
\hline $\mathbf{T}_{1}$-control & 42.53 & 43.40 & 22.25 & 22.53 \\
\hline $\mathrm{T}_{2}$-Mancozeb @ $2.5 \mathrm{~g} \mathrm{~L}^{-1}(3$ sprays $)$ & 45.40 & 51.30 & 24.06 & 30.31 \\
\hline $\mathrm{T}_{3}$-Silicon soil application $\left(150 \mathrm{~kg} \mathrm{ha}^{-1}\right)$ & 53.60 & 59.26 & 29.17 & 34.60 \\
\hline $\mathrm{T}_{4}$ - Silicon soil application $\left(300 \mathrm{~kg} \mathrm{ha}^{-1}\right)$ & 54.96 & 61.53 & 30.19 & 37.01 \\
\hline $\mathrm{T}_{5}$ - Silicic acid @ $2 \mathrm{ml} \mathrm{L}^{-1}$ (2 sprays) & 54.16 & 54.63 & 29.14 & 32.03 \\
\hline $\mathrm{T}_{6}$ - Silicic acid @ $2 \mathrm{ml} \mathrm{L}^{-1}$ (3 sprays) & 55.36 & 59.80 & 30.82 & 37.17 \\
\hline $\mathrm{T}_{7}$ - Silicic acid @ $4 \mathrm{ml} \mathrm{L}^{-1}$ (2 sprays) & 58.33 & 63.40 & 31.61 & 37.46 \\
\hline S.Em \pm & 0.44 & 0.78 & 0.91 & 1.76 \\
\hline CD at $5 \%$ & 1.36 & 2.42 & 2.79 & 5.28 \\
\hline
\end{tabular}

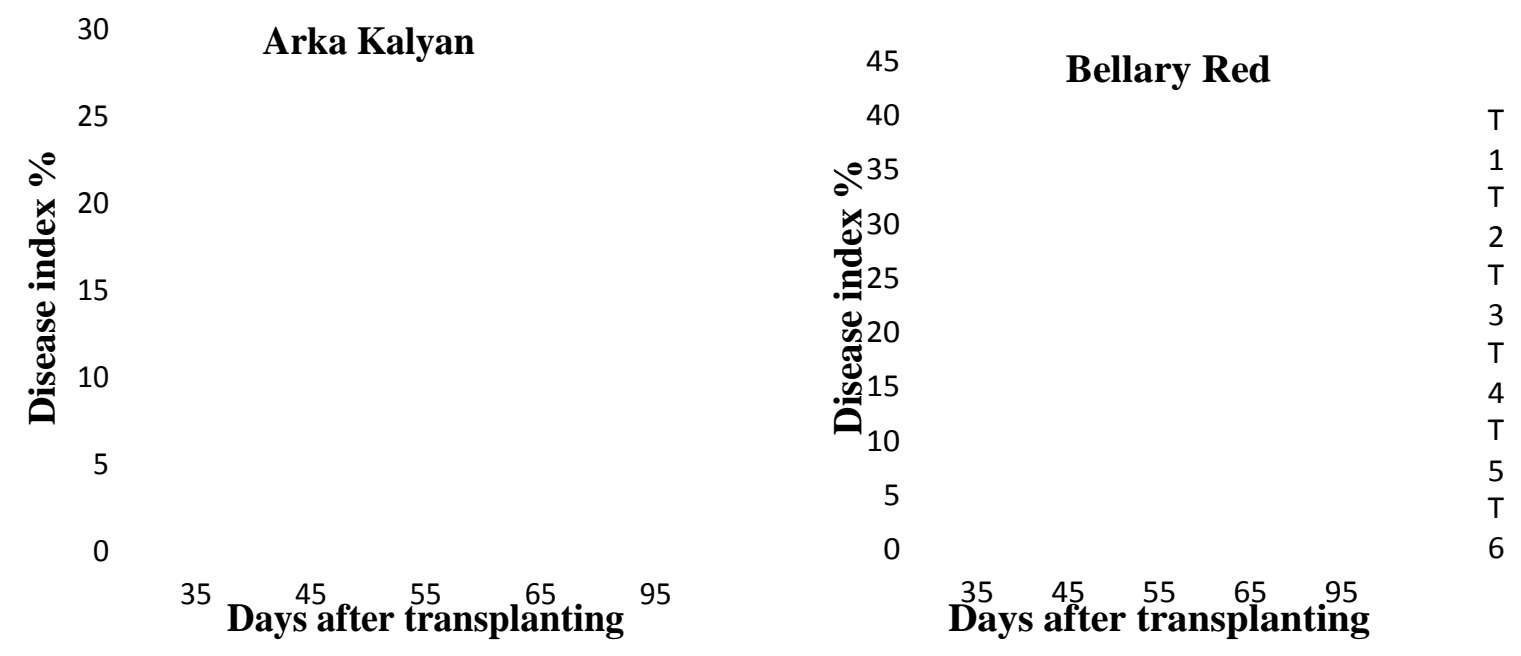

Fig.2 Effect of silicon on severity of purple blotch disease in onion at different stages of crop

Legends growth.

$\mathbf{T}_{\mathbf{1}}$-Control, $\mathbf{T}_{\mathbf{2}}$-Mancozeb @ $2.5 \mathrm{~g} \mathrm{~L}^{-1}$ (3 sprays), $\mathbf{T}_{\mathbf{3}}$-Silicon soil application $\left(150 \mathrm{~kg} \mathrm{ha}^{-1}\right), \mathbf{T}_{\mathbf{4}^{-}}$- Silicon soil application (300 $\left.\mathrm{kg} \mathrm{ha}^{-1}\right), \mathbf{T}_{5^{-}}$Silicon@ $2 \mathrm{ml} \mathrm{L}^{-1}$ (2 sprays), $\mathbf{T}_{6}-$ Silicon@ $2 \mathrm{ml} \mathrm{L}^{-1}$ (3 sprays), $\mathbf{T}_{7^{-}}$Silicon@ $4 \mathrm{ml}$ $\mathrm{L}^{-1}(2$ sprays) 
Observations on yield parameters revealed that average weight of bulb and total bulb yield per plot varied significantly between treatments in both the varieties (Table 3).

Significantly higher bulb weight was recorded in all other treatments over untreated control. Application of both the sources of silicon treatments was significantly superior to untreated control or standard check in Arka Kalyan variety.

Further, among the silicon treatments, highest bulb weight of $58.33 \mathrm{~g}$ was observed in $\mathrm{T}_{7}$ treatment (two spryas of silicic acid @ $4 \mathrm{ml}$ $\mathrm{L}^{-1}$ ) followed by in $\mathrm{T}_{6}$ treatment (three sprays of silicic acid @ $2 \mathrm{ml} \mathrm{L}^{-1}$ ) which was on par with in $\mathrm{T}_{5}$ treatment (two sprays of silicic acid (a) $2 \mathrm{ml} \mathrm{L}^{-1}$ ) and in $\mathrm{T}_{4}$ treatment (soil application of silicon@ $300 \mathrm{~kg} \mathrm{ha}^{-1}$ ).

In Bellary Red variety, highest bulb weight of $63.40 \mathrm{~g}$ was observed in $\mathrm{T}_{7}$ treatment (silicic acid spray@4 $\mathrm{ml} \mathrm{L}^{-1}$ ) which was on par with $\mathrm{T}_{4}$ treatment (silicon soil application @ 300 $\mathrm{kg} \mathrm{ha}^{-1}$ ) followed by $\mathrm{T}_{6}$ treatment (silicic acid spray@ $2 \mathrm{ml} \mathrm{L}^{-1}, 3$ sprays) and $\mathrm{T}_{3}$ treatment (soil application of silicon@ $150 \mathrm{~kg} \mathrm{ha}^{-1}$ ).

Total bulb yield per hectare calculated based on individual plot yield varied between 22.25 tons (untreated control) and 31.61 tons $\left(\mathrm{T}_{7}\right.$ silicic acid spray@4 $\mathrm{ml} \mathrm{L}^{-1}, 2$ sprays) in Arka Kalyan variety and between 22.53 tons and 37.46 tons in Bellary Red variety.

Prakash et al., (2011) revealed that, there was a significant increase in grain and straw yield with the application of foliar silicic acid at 2 and $4 \mathrm{ml} \mathrm{L}^{-1}$ alone and along with half dose of pesticide.

Malav et al., (2015) also reported augmented grain and straw yield in rice upon application of silicon along with improved nutrient uptake. Plant available $\mathrm{Si}$ (acetic acid extractable Si) content of the experimental plot before start of the experiment was $116 \mathrm{~kg}$ $\mathrm{ha}^{-1}$ and it was in the higher range of silicon availability (Narayanaswamy and Prakash, 2009 and Narayanaswamy and Prakash, 2010). Soil pH was neutral (7.05) and EC was $0.383 \mathrm{dSm}^{-1}$.

The leaf and bulb samples analysed after harvesting the crop recorded higher silicon content of leaves in all the treatments receiving silicon when compared to treatments which did not receive silicon (Table 4).

Among the treatments, highest silicon content was recorded in $\mathrm{T}_{7}$ (application of two spryas of silicic acid @ $4 \mathrm{ml} \mathrm{L}^{-1}$ ) followed by $\mathrm{T}_{6}$ (application of three sprays of silicic acid @ 2 $\mathrm{ml} \mathrm{L}^{-1}$ ) and $\mathrm{T}_{5}$ (application of two spryas of silicic acid @ $\left.2 \mathrm{ml} \mathrm{L}^{-1}\right)$ in both the varieties.

Silicon content in bulb was significantly higher in $\mathrm{T}_{4}$ (silicon soil application@ $300 \mathrm{~kg}$ $\mathrm{ha}^{-1}$ ) followed by $\mathrm{T}_{3}$ (silicon soil application @ $150 \mathrm{~kg} \mathrm{ha}^{-1}$ ) when compared with all other treatments in both the varieties.

However, foliar application did not increase Si content in bulb. Present observations are in line with the observations made by $\mathrm{Lu}$ et al., (2008) who reported enhanced accumulation of silicon in asparagus root and shoot with $\mathrm{Si}$ application when compared with untreated control plants.

Differences in silicon content of leaf and bulb observed in present study is in line with the report of Currie and Perry (2007) who reported that different parts of the same plant can have large differences in the accumulation of $\mathrm{Si}$. 
Table.4 Effect of silicon application on its contentinleaf and bulb of onion at harvest

\begin{tabular}{|c|c|c|c|c|}
\hline \multirow[t]{2}{*}{ Treatments } & \multicolumn{2}{|c|}{ Si content in leaf $(\%)$} & \multicolumn{2}{|c|}{ Si content in bulb $(\%)$} \\
\hline & Arka Kalyan & Bellary Red & Arka Kalyan & Bellary Red \\
\hline$T_{1}$-control & $\begin{array}{c}0.78 \\
(5.06)^{*}\end{array}$ & $\begin{array}{c}0.79 \\
(5.11)\end{array}$ & $\begin{array}{c}0.30 \\
(3.15)\end{array}$ & $\begin{array}{c}0.26 \\
(2.95)\end{array}$ \\
\hline $\mathrm{T}_{2}$-Mancozeb @ $2.5 \mathrm{~g} \mathrm{~L}^{-1}$ (3 sprays) & $\begin{array}{c}0.75 \\
(4.95)\end{array}$ & $\begin{array}{c}0.83 \\
(5.22)\end{array}$ & $\begin{array}{c}0.30 \\
(3.15)\end{array}$ & $\begin{array}{c}0.28 \\
(3.05)\end{array}$ \\
\hline $\mathrm{T}_{3}$-Silicon soil application $\left(150 \mathrm{~kg} \mathrm{ha}^{-1}\right)$ & $\begin{array}{c}1.07 \\
(5.93)\end{array}$ & $\begin{array}{c}1.17 \\
(6.19)\end{array}$ & $\begin{array}{c}0.43 \\
(3.76)\end{array}$ & $\begin{array}{c}0.33 \\
(3.30)\end{array}$ \\
\hline $\mathrm{T}_{4^{-}}$Silicon soil application $\left(300 \mathrm{~kg} \mathrm{ha}^{-1}\right)$ & $\begin{array}{c}1.06 \\
(5.90)\end{array}$ & $\begin{array}{c}1.15 \\
(6.15)\end{array}$ & $\begin{array}{c}0.44 \\
(3.79)\end{array}$ & $\begin{array}{c}0.41 \\
(3.69)\end{array}$ \\
\hline $\mathrm{T}_{5^{-}}$Silicic acid @ $2 \mathrm{ml} \mathrm{L}^{-1}$ (2 sprays) & $\begin{array}{c}1.33 \\
(6.60)\end{array}$ & $\begin{array}{c}1.30 \\
(6.52)\end{array}$ & $\begin{array}{c}0.27 \\
(2.99)\end{array}$ & $\begin{array}{c}0.22 \\
(2.68)\end{array}$ \\
\hline $\mathrm{T}_{6}$ - Silicic acid @ $2 \mathrm{ml} \mathrm{L}^{-1} \quad$ (3 sprays) & $\begin{array}{c}1.34 \\
(6.64)\end{array}$ & $\begin{array}{c}1.33 \\
(7.06)\end{array}$ & $\begin{array}{c}0.28 \\
(3.03)\end{array}$ & $\begin{array}{c}0.26 \\
(2.93)\end{array}$ \\
\hline $\mathbf{T}_{7^{-}}$Silicic acid @ $4 \mathrm{ml} \mathrm{L}^{-1}$ (2 sprays) & $\begin{array}{c}1.61 \\
(7.28)\end{array}$ & $\begin{array}{c}1.61 \\
(7.27)\end{array}$ & $\begin{array}{c}0.31 \\
(3.17)\end{array}$ & $\begin{array}{l}0.30 \\
(3.14)\end{array}$ \\
\hline S.Em \pm & 0.16 & 0.25 & 0.09 & 0.15 \\
\hline CD at $5 \%$ & 0.49 & 0.79 & 0.29 & 0.48 \\
\hline
\end{tabular}

Si has been thought to protect the plants through mechanical strengthening of the plant and also it is known to involve in the expression of a large spectrum of inducible defense responses and prime plants for enhanced defense in response to pathogen attack (Van Bockhaven et al., 2013). Reduction in purple blotch disease and increase in yield of onion observed in the present investigation might be due to different mechanisms of action of $\mathrm{Si}$ which needs further investigation. However, it is evident from the present study that the $\mathrm{Si}$ application helps in reducing the purple blotch disease incidence and severity in onion and hence could be used as one of the eco-friendly strategies in disease management.

\section{References}

Abdul Kareem M., Amruta S. Bhat, Krishna D. Kurubetta, Mesta R. K., Allolli, T. B. Ajjappalavar, P. S. Shweta K., Dileepkumar Masuthi and Waseem M.A., 2018. Evaluation of silicon and bioformulations for the management of purple blotch disease of onion. Res J. Chem. Environ. Sci. 6 (1):46-50 
Anonymous. 2013. Package of practice of horticultural crops. Pub.UHS Bagalkot, p. 120

Buck, G. B., Korndorfer, G. H., Nolla, A. and Coelho, L. 2008. Potassium silicate as foliar spray and rice blast control. Journal of Plant Nutrition. 31: 231-237.

Chowdappa, P., Sandhya, H. and ReddiBhargavi, B. 2012. Diversity analysis of Alternaria porri(Ellis) Cif. causal organism of purple leaf blotch of onion. International J. Innovative Hort.1(1): 11-17.

Cooke, J. and Leishman, M. R. 2011. Is plant ecology more siliceous than we realize? Trends in Plant Science.16:61-68.

Currie, H. A. and Perry, C. C. 2007. Silica in plants: biological, biochemical and chemical studies. Annals of Botany. 100: 1383-1389.

Datnoff, L. E., K. W. Seebold and F. J. Correa-Victoria. 2001. Use of silicon for integrated disease management:reducing fungicide applications andenhancing host plant resistance. In: Siliconin agriculture. Datnoff, L. E., Snyder G. H. and Korndorfer G. H. (Eds.). Elsevier Science, The Netherlands, pp. 171-184.

Eckert, J. W. 1988. Historical development of fungicide resistance in plant pathogens. In: Fungicide Resistance in North America.C. J. Delp (ed) American Phytopathological Society Press, pp 1-3.

Fauteux, F., Remus-Borel, W., Menzies, J. G. and Belanger, R.R. 2005. Silicon and plant disease resistance against pathogenic fungi. FEMS Microbiology Letters.249: 1-6.

Guevel, M. H., Menzies, J. G. and Belanger, R. R. 2007. Effect of root and foliar applications of soluble silicon on powdery mildew control and growth of wheat plants. Eur. J. Plant Pathol.119: 429-436.

Heckman, J. R. Johnston, S. and Cowgill, W.
2003. Pumpkin yield and disease response to amending soil with silicon. Hort. Sci. 38(4):552-554.

Holm, A. L., Rivera, V. V., Secor, G. A. and Gudmestad, N. C. 2003. Temporal sensitivity of Alternaria solani isolates to foliar fungicides. Am. J. Potato Res. 80: 33-40.

Kabalan, L., Lagauche, A., Delvaux, B. and Legrève, A. 2012. Silicon reduces black sigatoka development in banana. Plant Dis. 96(2): 273-278.

Khaing, Ei., Ei., Ahmad, J. A. M., Yun, W. M. and Ismail, M. R. 2014. Effects of silicon, copper and zinc applications on sheath blight disease severity on rice. World J. Agricultural Res. 2(6): 309314.

Korndorfer, G. H., Snyder, G. H., Uloa, M., and Datnoff, L. E. 2001. Calibration of soil and plant silicon for rice production. J. Plant Nutr. 24(7): 10711084.

Kumbargire, G. A., Swamy, G. S. K. and Kalatippi, A. S. 2016. Influence of diatomaceous earth as source of silicon on leaf nutrient status and yield attributing charcters of banana cv. Grand Naine. The Bioscan 11(1): 435-438.

Lalithya, K. A., Bhagya, H. P., Bharathi, K. and Hipparagi, K. 2014. Response of soil and foliar application of silicon and micronutrients on leaf nutrient status of sapota. The Bioscan 9(1): 159-162.

Lemes, E. M., Mackowiak, C.L., Blount, A., Marois, J. J., Wright, D. L., Coelho, L. and Atnoff, L. E. 2011. Effects of silicon applications on soybean rust development under greenhouse and field conditions. Plant Dis. 95:317-324.

Lu, G., Jian, W., Zhang, J., Zhou, Y. and Cao, J. 2008. Suppressive effect of silicon nutrient on Phomopsis stem blight development in asparagus. Hort. Sci.43(3):811-817.

Ma, J. F., Miyake, Y. and Thakahashi, E. 
2002. Silicon as a beneficial element for crop plants. In: Silicon in agriculture, Datnoff, L.E., Snyder, G.H. and Korndorfer, G.H., (Eds). Elsevier Science, The Netherlands, pp:17-39.

Malav, J. K., Patel, K. C. and Sajid, M. 2015. Influence of silicon fertilization on yield and nutrients uptake ( $\mathrm{Si}, \mathrm{P}, \mathrm{K}, \mathrm{S} \& \mathrm{NA}$ ) of rice (Oryza sativa L.). The Ecoscan 9(1\&2):629-634.

Narayanaswamy and Prakash, N. B. 2009. Calibration and categorization of plant available soil silicon as extracted by different extractants in soils of south India. J. Plant Nutr.32(8):1237-1254.

Narayanaswamy and Prakash, N. B. 2010. Evaluation of selected extractants for plant available silicon in soils of the southern India.Communication in soil science and plant analysis, 41(8):977 989

Prakash, N. B., Chandrashekar, N., Mahendra, C., Patil, S. U., Thippeshappa, G. N. and Laane, H. M. 2011. Effect of foliar spray of soluble silicic acid on growth and yield parameters of wetland rice in hilly and coastal zone soils of Karnataka, South India. J. Plant Nutr.34: 1883-1893.

Romero, A., Munevar, F. and Cayon, G., 2011, Silicon and plant diseases a review, Agronomía Colombiana, 29(3): 473-480.

Seebold, K. W., Datnoff, L. E., CorreaVictoria, F. J., Kucharek, T. A. and Snyder, G.H. 2000. Effect of silicon rate and host resistance on blast, scald, and yield of upland rice. Plant Dis.84:871876.

Sharma, S. R. 1986. Effect of fungicidal sprays on purple blotch and bulb yield of onion. Indian Phytopath. 39: 78-82.

Shetty, R., Jensen, B., Shetty, N. P., Hansen, M., Hansen, C. W., Starkey, K. R. and Jorgensen, H. J. L. 2012. Silicon induced resistance against powdery mildew of roses caused by Podosphaera pannosa. Plant Pathology. 61: 120131.

Sundarraj, N., Nagaraju, S., Venkataramu, M. N., and Jagannath, M. L. 1972. Design and analysis of field experiments. Directorate of Research, University of Agricultural Sciences Bangalore, p. 419.

Van Bockhaven, J. De Vieesschauwer, D. and Hofte, M. 2013. Towards establishing broad-spectrum disease resistance in plants: silicon leads the way. J. Experimental Botany, 64(5): 1281-1293.

\section{How to cite this article:}

Mohammad Haroon, Amruta S. Bhat, N.B. Prakash, K.T. Rangaswamy and Lingaiah. H.B. 2020. Effect of Silicon on Incidence and Severity of Purple Blotch Disease (Alternaria porri (Ellis) Cif.) in Onion (Allium cepa L.). Int.J.Curr.Microbiol.App.Sci. 9(02): 429-439. doi: https://doi.org/10.20546/ijcmas.2020.902.053 